\title{
PEDOLOGICAL CHARACTERIZATION AND LAND USE AND OCCUPATION: INFLUENCES ON WATER QUALITY IN A WATERSHED LOCATED IN THE ZONA DA MATA (MG)
}

\section{LUANA C. R. ANDRADE ${ }^{1}$, EDUARDO A. G. MARQUES ${ }^{2}$, THAÍS DE C. FELICORI ${ }^{3}$}

ABSTRACT: In order to verify the influence of class and use and occupation of land on water quality, it was performed the characterization and analyzes of land use and monitoring of seven springs inserted in a watershed located in the rural of Viçosa city - Minas Gerais (MG) state, in Brazil. Through soil analyzes, carried out in five different profiles, it was possible to identify three distinct pedological classes: Argisol, Cambisol and Latosol. Furthermore, the concentrations of Fe, $\mathrm{Mn}, \mathrm{Cu}, \mathrm{Zn}, \mathrm{Cr}, \mathrm{Cd}, \mathrm{Pb}$ and $\mathrm{Ni}$ were identified in each of the horizons in the considered profiles. Water samples were collected and analyzed monthly, over eight months, twenty two parameters of water quality. Comparing the results of each survey, it was possible to identify a relation between water quality and land use in the round of the springs, considering color, BOD, DO, E. coli and Mn as the most affected parameters, influenced mainly by soil characteristics and the presence of a large percentage of pasture in the study area.

KEYWORDS: soil characteristics, water quality, rural watershed.

\section{CLASSIFICAÇÃO PEDOLÓGICA E USO E OCUPAÇÃO DO SOLO: INFLUÊNCIAS NA QUALIDADE DA ÁGUA DE UMA SUB-BACIA HIDROGRÁFICA LOCALIZADA NA ZONA DA MATA (MG).}

RESUMO: Com objetivo de verificar a influência da classe e o uso e a ocupação do solo na qualidade da água, realizou-se a caracterização e a análise do uso do solo e o monitoramento de sete nascentes inseridas em uma bacia hidrográfica localizada na zona rural do município de ViçosaMG. Por meio das análises de solo, realizadas em cinco perfis diferentes, foi possível identificar três classes pedológicas distintas: Argissolos, Cambissolos e Latossolos. Além disso, foram identificadas as concentrações de $\mathrm{Fe}, \mathrm{Mn}, \mathrm{Cu}, \mathrm{Zn}, \mathrm{Cr}, \mathrm{Cd}, \mathrm{Pb}$ e $\mathrm{Ni}$ em cada um dos horizontes dos perfis considerados. Foram coletadas amostras de água e analisados, mensalmente, ao longo de oito meses, vinte e dois parâmetros de qualidade da água. Confrontando os resultados de cada levantamento, foi possível identificar uma relação entre a qualidade da água e o uso do solo no entorno das nascentes, sendo cor, DBO, OD, E. coli e Mn os parâmetros mais afetados, influenciados, principalmente, pelas características do solo e da presença de uma grande porcentagem de pastagem na área de estudo.

PALAVRAS-CHAVE: características do solo, qualidade da água, bacia hidrográfica rural.

\footnotetext{
${ }^{1}$ Engenheira Ambiental - Departamento de Engenharia Civil - Universidade Federal de Viçosa.

${ }^{2}$ Geólogo, Professor Associado - Departamento de Engenharia Civil - Universidade Federal de Viçosa.

${ }^{3}$ Engenheira Ambiental - Departamento de Engenharia Civil - Universidade Federal de Viçosa.

Recebido pelo Conselho Editorial em: 27-4-2012

Aprovado pelo Conselho Editorial em: 6-2-2013
} 


\section{INTRODUCTION}

The watershed of Palmital stream has great importance for Viçosa city - Minas Gerais (MG) state, in Brazil. Besides local importance, because it is a watershed where large quantities of water are captured for public supply in the city of Viçosa-MG, the watershed of Palmital stream also presents regional importance, since its characteristics, both in relation to land use, with a predominance of pasture, and in relation to its physical characteristics (topography, geology, pedology and water resources), make it representative of most watersheds of Zona da Mata, in Minas Gerais.

The water demand for public supply in the urban area of Viçosa-MG has increased considerably in recent years, having been necessary the rationalization of water use in times of drought. Moreover, the main sources of supply of the municipality are in increasing state of degradation due to the release of untreated domestic sewage, property speculation and the removal of permanent preservation areas, which has caused siltation and contamination of watercourses (SOARES et al., 2011).

Several studies have shown concern for the characterization and spatial distribution of the sources of anthropogenic pollution in watersheds located in rural areas, pointing to its relation with results of contamination of water bodies, for example, ANDRADE (2010), ANDRADE et al. (2007), SANTOS (2007) and DONADIO et al. (2005).

According to TUNDISI (2006), the watercourses receive from the watersheds and from the drainage network in which they are inserted a large amount of organic and inorganic compounds, which form the basis of the chemical composition of water. VON SPERLING (2011) also states that water features are a result of natural phenomena and human activities, and may be said that, in general, the quality of a particular source of water is a function of the use and occupation of land in the watershed.

DONADIO et al. (2005) evaluated the water quality of four springs in the watershed of the Rico stream (state of São Paulo), two of them with remaining natural vegetation and two with a predominance of agriculture. It was observed that the springs with remaining natural vegetation showed better water quality than the springs in agricultural use, and the variables color, turbidity, alkalinity and total nitrogen explained more these differences.

One may see, therefore, that the mapping of water quality and assessment of the characteristics associated with soil and human activities in a watershed help to identify the most vulnerable areas and facilitate the investigation on the source of contamination of the watershed, corroborating with MENEZES et al. (2009).

In this context, the present work aimed to evaluate the influence of soil types (pedological classification), physical characteristics, and use and occupation of soil on water quality in a subbasin of Palmital stream, located in rural area of Viçosa-MG.

\section{MATERIAL AND METHODS}

The watershed of Palmital stream is located in the rural are of Viçosa city, belonging to the Zona da Mata area, in Minas Gerais state, between the meridians of $42^{\circ} 50^{\prime} \mathrm{W}$ and $42^{\circ} 52^{\prime} \mathrm{W}$ and between parallels $20^{\circ} 49^{\prime} \mathrm{S}$ and $20^{\circ} 51^{\prime} \mathrm{S}$. The study area comprises a sub-basin of Palmital stream, with a total area of 131ha, where there are located some of the main springs of São Bartolomeu stream, one of the springs that supply Viçosa city.

Viçosa has well-defined periods with cold and dry winters and hot and humid summers, as shown in Figure 1. This graph was generated using data collected from the Climatological Station of the Department of Agricultural Engineering of Federal University of Viçosa (UFV), and it shows that the rainy season is concentrated in the months from September to December. 


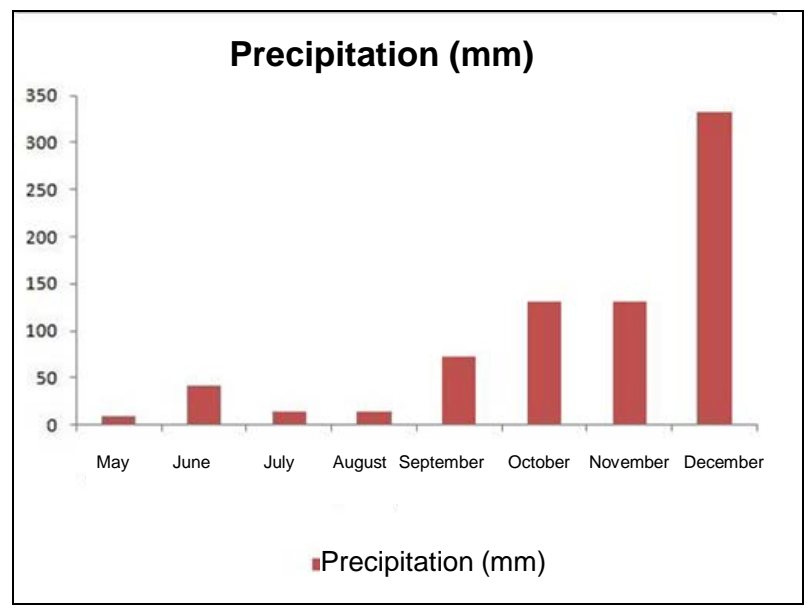

FIGURE 1. Monthly data of precipitation from May to December, 2009, for Viçosa-MG. Source: ANDRADE, 2010.

The main land uses identified in the sub-basin are pasture, forest, eucalyptus, coffee, maize, beans, orchards, sugar cane and cattail. Figure 2 shows the proportion of area occupied by the main uses identified in the study area.

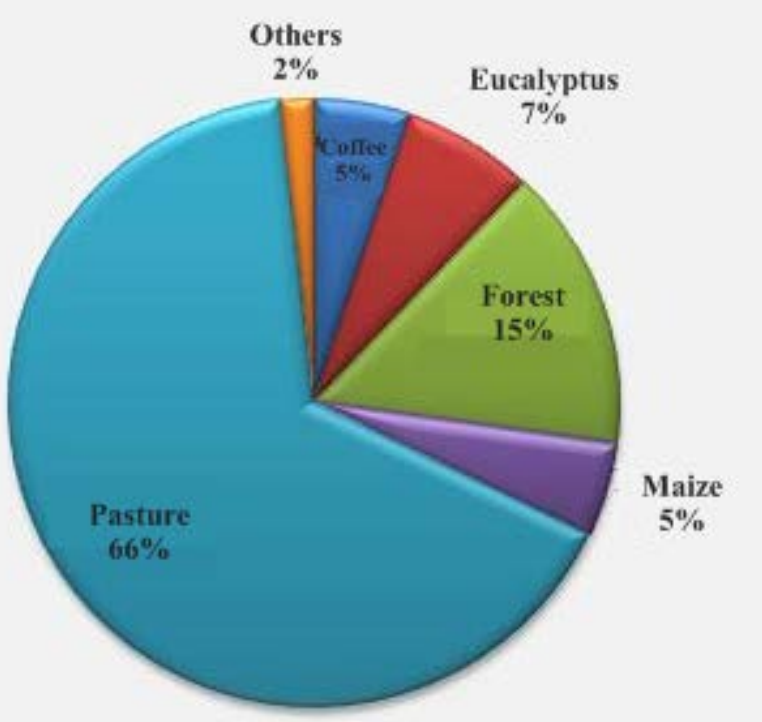

FIGURE 2. Land use and occupation. Proportion of area used by the main uses. Source: ANDRADE, 2010.

The sub-basin has 15 springs and one exoreic drainage network, open drainage that is intended to perennial and periodical rivers, sparsely branched and dendritic type, which typically occurs on rocks of uniform strength or horizontal stratified rocks. The existing watercourses in the sub-basin are, in general, shallow and narrow.

The research was carried out from the acquisition of information regarding the hydrographic network, the use of soil and water, geology, mineralogy and local pedology, followed by physicalchemical and microbiological analyzes of surface waters. We proceeded, after, to the interpretation and evaluation of results obtained through correlations and graphic analyzes.

The pedological survey was carried out in detail scale $(1: 5,000)$, with the aid of IKONOS image, map elevation and slope map, derived from a Digital Model of Elevation with a spatial resolution of $10 \mathrm{~m}$, with the purpose of obtaining information about the relief units of the studied area. For characterization purposes, five soil profiles were selected and described (whose location is in Figure 3), selected based on different landforms found in the watershed, in which information considered representative of the environmental conditions of the area studied was also collected. 
After the description of the soil profiles, samples of the major horizons of the five profiles described were collected, in a total of 27 samples, which were sent to the laboratories of the Department of Soils of the Federal University of Viçosa (UFV) for physical, chemical and mineralogical analyzes. For soil classification, it was used the methodology proposed by EMBRAPA (2006), and we also made mineralogical analyzes of the natural clay fraction and of the elements: $\mathrm{Fe}, \mathrm{Mn}, \mathrm{Cu}, \mathrm{Zn}, \mathrm{Cr}, \mathrm{Cd}, \mathrm{Pb}$ and $\mathrm{Ni}$, in order to detect influence of the soil on water quality. The main analysis and methodologies are listed in Table 1.

TABLE 1. Methods used for soil analyzes.

\begin{tabular}{cc}
\hline Analysis & Method \\
\hline $\mathrm{pH}$ & $\mathrm{pH}$ on water, $\mathrm{KCl}$ and $\mathrm{CaCl}_{2}-1: 2,5$ Ratio \\
\hline $\mathrm{Fe}, \mathrm{Mn}, \mathrm{Cu}, \mathrm{Zn}, \mathrm{Cr}, \mathrm{Cd}, \mathrm{Pb}$ and $\mathrm{Ni}$ & Nitropercloric extractor, \\
& spectrophotometry of plasma emission Perkim- \\
& Elmer 3300-DV Optimal \\
\hline Mineralogy & Natural Clay - X-ray \\
\hline
\end{tabular}

The results obtained for the elements $\mathrm{Fe}, \mathrm{Mn}, \mathrm{Cu}, \mathrm{Zn}, \mathrm{Cd}, \mathrm{Cr}, \mathrm{Pb}$ and $\mathrm{Ni}$ were evaluated and compared with quality reference values and with prevention values for agricultural use, established by the Normative Deliberation of COPAM No. 166/11, which establishes the quality reference values for the state of Minas Gerais. It is noteworthy that, for some parameters, there are no reference values in ND 166/11.

Although the method used does not match the described methodology presented by EPA 3050B (1996), required by CONAMA Resolution No. 420/09, which establishes criteria and guiding values of soil quality for the presence of chemicals, it was possible to compare the values, since it also makes use of strong acid to extract the inorganic substances, which dissolves nearly all the elements which could become environmentally available. The method does not quantify the elements connected to silicate structures, as well as proposed by EPA 3050B (1996), as they are not dissolved by these procedures and are typically not mobile in the environment.

The soil classification was performed by analyzing the results of field work and laboratory analyzes proceeding to the extrapolation to the entire area of the data with the help of ArcGIS 9.2 software. In the field, it was determined which types of soil occur for each type of relief (depending on the steepness of the slope). Subsequently, these classes were delimited for the same types of relief using the GIS.

For the monitoring of water quality, after the research of local hydrographic network, we proceeded to the selection of monitoring points, aiming to verify the quality of surface water in the main springs. The allocation of the points was carried out in order to cover the entire area of the watershed of Palmital stream.

Samples were collected monthly from May to December, 2009, in seven springs (Figure 4), and the process of surface water sampling was performed according to the recommendations of international standards of monitoring of water quality (EPA, 1999).

In each of the selected points, we performed an analysis of the parameters alkalinity, color, turbidity, electrical conductivity (EC), $\mathrm{pH}$, total solids, chemical oxygen demand (COD), biochemical oxygen demand (BOD), dissolved oxygen (DO), temperature, chlorides, total coliforms, E. coli, nitrate, total iron, total manganese, total chromium, total zinc, total lead, total nickel, total cadmium and total copper, totaling 22 parameters.

The analyzes were performed at the Laboratory of the Division of Water and Sewage of UFV and at the Laboratory of Organic Matter and Solid Waste of the Department of Soils of UFV, following the methodologies related to APHA (2005), except for metals. 
For quantification of metals in water, a gross sample (no filter) was used, proceeding to the nitropercloric extraction, as performed in soil samples, identifying the total amounts of each metal present in the samples. This method is not standard for analysis of water and it was used in order to compare with the results obtained in the soil analyzes.

The average of the results obtained in the eight monitoring campaigns carried out to evaluate the water quality in the monitored springs was compared to the standards established by CONAMA Resolution No. 357/05 existing for watercourses of class 2, aiming to identify the parameters that showed changes in their concentrations.

From the identification of the parameters of water quality that showed their concentrations above the standard allowed by legal norms (nonconformities) to watercourses class 2, we tried to establish relations with other available information (pedology, soil occupation and use, and anthropogenic activities) in order to identify the origin of the changes, proceeding, in this way, to the assessment of surface water quality.

\section{RESULTS AND DISCUSSION}

\section{Geological and pedological survey}

ANDRADE (2010) states that, through field research conducted in the area, it was possible to detect the gneiss as the main rock type in this sub-basin. Despite the predominance of gneiss, the relation between pedology and topography, already observed by TERAMOTO et al. (2001) and BARDALES et al. (2007), explains the different classes and characteristics of soil in the sub-basin.

We identified three classes of soils in sub-stream of Palmital basin: Haplic Cambisol, RedYellow Latosol and Red-Yellow Argisol. The semi-detailed soil map of the sub-basin is shown in Figure 3.

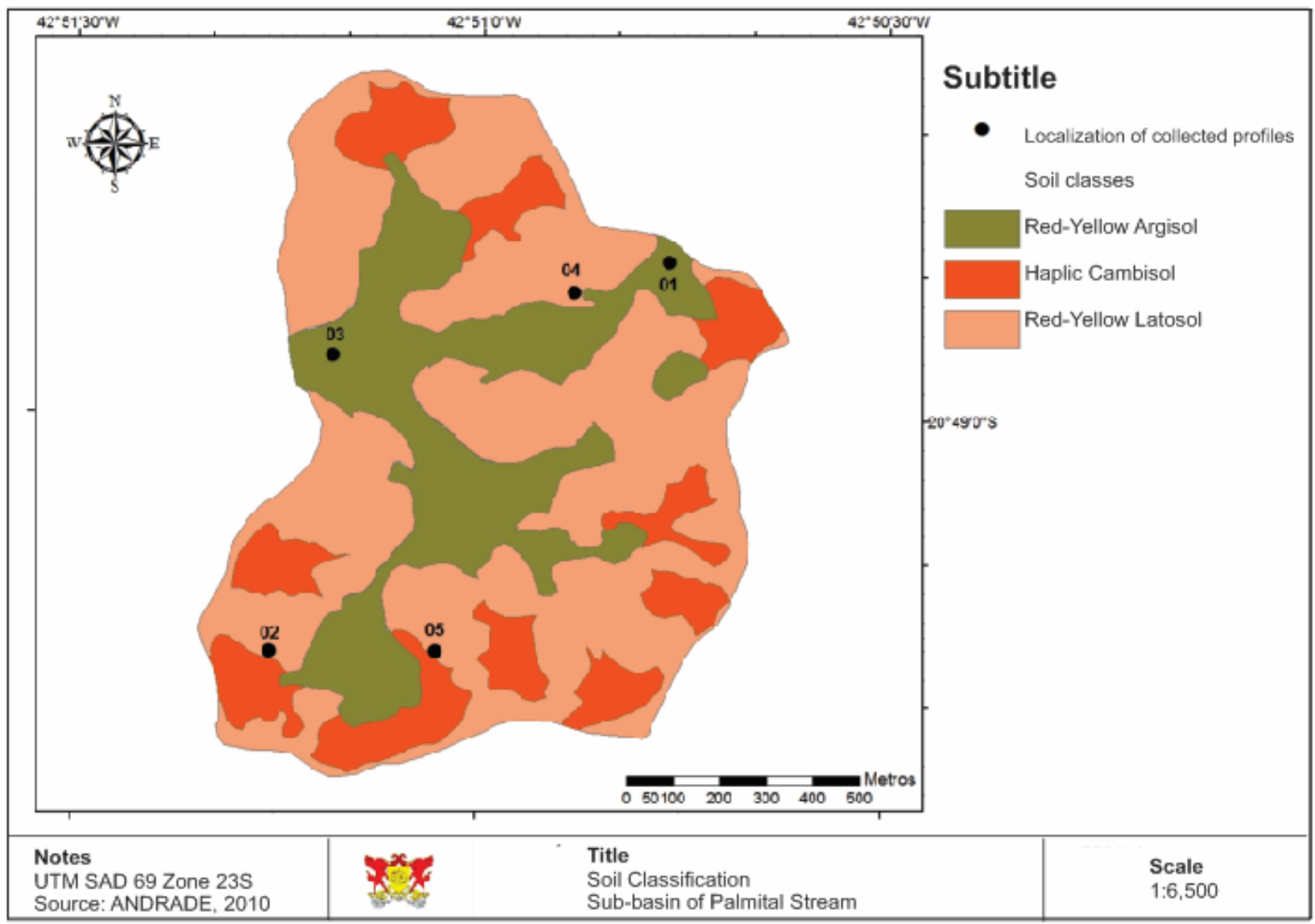

FIGURE 3. Semi-detailed map of sub-basin soil. 
In this sense, it is possible to affirm that, due to the uniformity of geology in the study area, the differences in water quality found among the sources monitored are hardly related to the type of rock present at the site, which are influenced mainly by topography and soil use in the sub-basin, as may be observed below.

The results for the analyzes of the elements $\mathrm{Cu}, \mathrm{Zn}, \mathrm{Cd}, \mathrm{Cr}, \mathrm{Pb}$ and $\mathrm{Ni}$ were compared with reference values of quality (VRQ) and research (VI) for agricultural use established by Normative Deliberation of COPAM No. 166/11.

It is understood by VRQ the concentration of a substance that defines the natural quality of the soil, and VI as the concentration of a substance in soil above which there are potential risks, direct or indirect, to human health.

Table 2 shows the results obtained for each of the elements mentioned in the various horizons of the five soil profiles collected.

TABLE 2. Concentration of the elements $\mathrm{Fe}, \mathrm{Mn}, \mathrm{Cu}, \mathrm{Zn}, \mathrm{Cd}, \mathrm{Pb}$ and $\mathrm{Ni}$ in the different soil profiles.

\begin{tabular}{|c|c|c|c|c|c|c|c|c|c|}
\hline Profile & Horizon & $\mathrm{Fe}$ & $\mathrm{Mn}$ & $\mathrm{Cu}$ & $\mathrm{Zn}$ & $\mathrm{Cd}$ & $\mathrm{Pb}$ & $\mathrm{Cr}$ & $\mathrm{Ni}$ \\
\hline \multirow{7}{*}{1} & Ap (0-20cm) & ---- & 67.20 & 4.61 & 785.57 & 0.27 & 7.42 & 10.24 & 4.50 \\
\hline & BA (20-33cm) & 93240.53 & 75.07 & 3.90 & 278.02 & 0.28 & 6.85 & 6.45 & 3.52 \\
\hline & Bt1 $(33-71 \mathrm{~cm})$ & 12964.85 & 36.21 & 5.00 & 127.31 & 0.32 & 7.50 & 7.28 & 4.03 \\
\hline & Bt2 (71-120cm) & 14278.66 & 6.40 & 4.46 & 19.71 & 0.34 & 8.25 & 7.57 & 4.02 \\
\hline & Bt3 (120-166cm) & 15947.05 & 10.5 & 3.8 & --- & 0.38 & 8.33 & 5.44 & 3.09 \\
\hline & BC (166-200cm) & 14676.65 & 5.83 & 4.11 & 16.11 & 0.36 & 8.86 & 5.46 & 3.06 \\
\hline & $\mathrm{BC}(166-200 \mathrm{~cm})$ & 18258.23 & 45.37 & 6.35 & 5.69 & 0.35 & 7.37 & 10.80 & 3.99 \\
\hline \multirow{4}{*}{2} & $\mathrm{AB}(22-38 \mathrm{~cm})$ & 17796.49 & 36.25 & 6.20 & 5.33 & 0.36 & 6.69 & 10.57 & 3.73 \\
\hline & BA (38-53cm) & 19758.03 & 13.22 & 6.76 & 5.51 & 0.39 & 7.33 & 10.76 & 4.13 \\
\hline & Bw1 (53-112cm) & 21688.77 & 10.55 & 6.59 & 5.27 & 0.41 & 7.55 & 10.91 & 4.01 \\
\hline & Bw2 (112-180cm) & 25288.65 & 3.05 & 7.15 & 5.56 & 0.56 & 8.69 & 12.05 & 4.03 \\
\hline \multirow{6}{*}{3} & Ap $(0-17 \mathrm{~cm})$ & 12170.68 & 149.37 & 6.13 & 6.98 & 0.29 & 11.13 & 4.68 & 3.10 \\
\hline & $\mathrm{AB}(17-30 \mathrm{~cm})$ & 13185.47 & 160.54 & 6.14 & 6.20 & 0.34 & 11.00 & 5.74 & 3.99 \\
\hline & Bt1 (30-64cm) & 20412.02 & 247.68 & 10.17 & 9.02 & 0.51 & 17.43 & 7.98 & 5.41 \\
\hline & Bt2 $(64-99 \mathrm{~cm})$ & 22754.88 & 169.88 & 13.45 & 8.83 & 0.58 & 18.30 & 9.16 & 6.53 \\
\hline & BC $(99-113 \mathrm{~cm})$ & 17677.24 & 117.62 & 9.81 & 7.28 & 0.48 & 16.05 & 8.38 & 5.42 \\
\hline & C (113-150cm) & 17912.92 & 240.83 & 7.63 & 7.21 & 0.47 & 14.68 & 7.18 & 4.89 \\
\hline \multirow{6}{*}{4} & Ap $(0-20 \mathrm{~cm})$ & 18740.04 & 184.88 & 6.26 & 5.97 & 0.58 & 13.19 & 9.61 & 5.33 \\
\hline & AB (20-37cm) & 20171.04 & 83.61 & 6.18 & 4.98 & 0.54 & 13.39 & 9.02 & 4.33 \\
\hline & BA (37-52cm) & 22737.19 & 44.33 & 6.83 & 5.44 & 0.64 & 13.41 & 8.87 & 4.56 \\
\hline & Bw1 (52-96cm) & 25297.97 & 53.52 & 7.11 & 6.22 & 0.66 & 15.09 & 9.14 & 6.03 \\
\hline & Bw2 (96-135cm) & 29831.77 & 30.42 & 8.21 & 6.45 & 0.74 & 16.29 & 10.14 & 6.66 \\
\hline & BC (135-175cm) & 12125.64 & 11.05 & 5.04 & 4.22 & 0.46 & 10.56 & 6.85 & 5.05 \\
\hline \multirow{4}{*}{5} & Ap (0-32cm) & 9317.07 & 3.99 & 2.70 & 3.24 & 3.72 & 9.99 & 3.62 & 3.54 \\
\hline & BA (32-50cm) & 17318.24 & 0.00 & 5.03 & 3.43 & 1.65 & 10.88 & 3.95 & 3.39 \\
\hline & $\mathrm{Bi}(50-82 \mathrm{~cm})$ & 13178.42 & 2.57 & 2.71 & 2.46 & 2.28 & 9.71 & 3.21 & 2.63 \\
\hline & $\mathrm{C}(82-120+\mathrm{cm})$ & 28392.57 & 13.84 & 4.87 & 4.32 & 3.86 & 16.98 & 6.02 & 5.17 \\
\hline
\end{tabular}

Obs.: All units in (mg. $\left.\mathrm{Kg}^{-1}\right)$

The obtained results show that only the parameters zinc on Ap horizon of Profile 1 and cadmium of Profile 05 for Ap and $C$ horizons do not meet the limits set by law, specifically with regard to metals. Both parameters extrapolated VRQ and VI. Naturally, tropical soils tend to have low levels of zinc and cadmium. High concentrations may be explained by the use of fertilizers. 
Phosphate fertilizers have concentrations of zinc in the range of 50 to $1450 \mathrm{mg}^{-\mathrm{kg}^{-1}}$ and of cadmium between 0.1 and 170mg.kg-1 (AMARAL SOBRINHO et al., 1992).

The provision of pig slurry in the soil may serve as a source of nutrients, according to the studies of GIROTTO (2007) and KESSLER et al. (2011), it may also have potential contaminant due to high concentration of zinc in the diets of the animals. The profiles 01 and 05 are located in a pasture area, and the second is also close to maize cultivation.

For iron and manganese parameters, there are no standards set by the Normative Deliberation of COPAM No. 166/11, since they have large variation of natural concentration in different types of soils in the State. However, it may be observed that the values obtained for iron concentrations are much higher than the other elements. The same occurs with the concentration values of manganese, which, in most cases, are superior to those of $\mathrm{Cu}, \mathrm{Zn}, \mathrm{Cd}, \mathrm{Cr}, \mathrm{Pb}$ and $\mathrm{Ni}$.

The $\mathrm{pH}$ has a direct influence on the availability and mobility of the metals in the soil, particularly regarding the elements Fe and $\mathrm{Mn}$. In general, availability and mobility of metals is greater in soils with low $\mathrm{pH}(<5.5)$, as is the case for most profiles analyzed.

The values of $\mathrm{pH}$ on water, measured for all horizons of five profiles evaluated, ranged between 5,03 and 6,24 for argisols (profiles 1 and 3), between 4,21 and 5,57 for the latosols (profiles 2 and 4), and between 3,88 and 4,53 to cambisols (profile 5). Thus, it may be said that, in addition to the mineralogical and geological factors, the $\mathrm{pH}$ may have influenced the high values found for the elements Fe and Mn.

The low $\mathrm{pH}$ values found, besides interfering with the availability of metals, may also have contributed to increase the mobility and leaching of these elements to deeper horizons, which may be verified by analyzing the variation of the concentration of metals along horizons of the soil profiles evaluated. It is noted, especially in the profile 5 , where $\mathrm{pH}$ values were the lowest $(\mathrm{pH}$ $<4.53$ ), the concentration increase of the different metals as the depth increases.

\section{Monitoring of water quality}

The standards used for the analysis of surface water quality were established by CONAMA Resolution No. 357/05, for watercourses class 2, since the drainages existing in the area have not yet been classified based on this resolution.

Table 3 shows the average results found for the sources monitored. Of the parameters analyzed, only DO, BOD, E. coli, color, pH, Lead, Chromium, Manganese and Zinc showed values that, in at least one analysis, have not met the limits of the law, which are analyzed in greater depth on the following topic. 
TABLE 3. Results of monitoring of water quality.

\begin{tabular}{|c|c|c|c|c|c|c|c|c|}
\hline & N1 & $\mathrm{N} 2$ & N3 & $\mathrm{N} 4$ & N5 & N6 & N7 & Standard \\
\hline $\begin{array}{l}\text { Alkalinity } \\
\left.\text { mg of } \mathrm{CaCO}_{3} / \mathrm{L}\right)\end{array}$ & 16.18 & 23.67 & 13.94 & 18.48 & 25.90 & 29.29 & 10.58 & --- \\
\hline $\begin{array}{l}\text { Cadmium (mg } \\
\text { of Cd/L) }\end{array}$ & 0.00 & 0.00 & 0.00 & 0.00 & 0.00 & 0.00 & 0.00 & $\begin{array}{c}0.001 \mathrm{mg} \text { of } \\
\mathrm{Cd} / \mathrm{L}\end{array}$ \\
\hline $\mathrm{EC}(\mu \mathrm{S} / \mathrm{cm})$ & 43.20 & 79.01 & 49.16 & 51.54 & 85.19 & 78.83 & 27.51 & --- \\
\hline $\begin{array}{l}\text { Lead (mg of } \\
\mathrm{Pb} / \mathrm{L})\end{array}$ & 0.00 & 0.01 & 0.01 & 0.02 & 0.01 & 0.01 & 0.01 & $\begin{array}{c}0.01 \mathrm{mg} \text { of } \\
\mathrm{Pb} / \mathrm{L}\end{array}$ \\
\hline $\begin{array}{l}\text { Chlorides (mg } \\
\text { of } \mathrm{Cl} / \mathrm{L} \text { ) }\end{array}$ & 0.71 & 1.44 & 1.80 & 1.36 & 1.20 & 1.71 & 1.37 & $\begin{array}{c}250 \mathrm{mg} \text { of } \\
\mathrm{Cl} / \mathrm{L}\end{array}$ \\
\hline $\begin{array}{l}\text { Copper (mg of } \\
\mathrm{Cu} / \mathrm{L} \text { ) }\end{array}$ & 0.04 & 0.05 & 0.02 & 0.01 & 0.02 & 0.02 & 0.04 & --- \\
\hline $\begin{array}{l}\text { Total } \\
\text { Coliforms }\end{array}$ & 18398.60 & 15767.65 & 1137.36 & 9151.70 & 16212.85 & 16934.45 & 11526.56 & --- \\
\hline Color (UH) & 95.63 & 265.38 & 36.25 & 42.00 & 361.25 & 345.88 & 108.75 & $75 \mathrm{UH}$ \\
\hline $\begin{array}{l}\text { Chromium (mg } \\
\text { of } \mathrm{Cr} / \mathrm{L} \text { ) }\end{array}$ & 0.00 & 0.09 & 0.03 & 0.05 & 0.08 & 0.12 & 0.05 & $\begin{array}{c}0.05 \mathrm{mg} \text { of } \\
\mathrm{Cr} / \mathrm{L}\end{array}$ \\
\hline $\begin{array}{l}\mathrm{BOD}(\mathrm{mg} \text { of } \\
\left.\mathrm{O}_{2} / \mathrm{L}\right)\end{array}$ & 10.46 & 11.04 & 10.98 & 9.76 & 9.81 & 6.38 & 8.04 & $\begin{array}{c}5 \mathrm{mg} \text { of } \\
\mathrm{O}_{2} / \mathrm{L} \\
\end{array}$ \\
\hline $\begin{array}{l}\text { COD (mg of } \\
\left.\mathrm{O}_{2} / \mathrm{L}\right)\end{array}$ & 76.95 & 47.23 & 50.64 & 51.58 & 45.64 & 72.18 & 56.21 & --- \\
\hline $\begin{array}{l}\text { E. coli } \\
\text { (org/100mL) }\end{array}$ & 884.00 & 1239.13 & 48.32 & 38.94 & 113.45 & 307.35 & 99.20 & $\begin{array}{c}1000 \\
\text { org } / 100 \mathrm{~mL}\end{array}$ \\
\hline $\begin{array}{l}\text { Total Iron (mg } \\
\text { of Fe/L) }\end{array}$ & 2.64 & 9.03 & 4.22 & 3.77 & 29.48 & 4.02 & 15.33 & --- \\
\hline $\begin{array}{l}\text { Total } \\
\text { Manganese } \\
(\mathrm{mg} \text { of } \mathrm{Mn} / \mathrm{L})\end{array}$ & 0.11 & 0.25 & 0.25 & 0.00 & 2.43 & 0.34 & 0.19 & $\begin{array}{l}0.1 \mathrm{mg} \text { of } \\
\mathrm{Mn} / \mathrm{L}\end{array}$ \\
\hline $\begin{array}{l}\text { Nickel (mg of } \\
\mathrm{Ni} / \mathrm{L})\end{array}$ & 0.00 & 0.00 & 0.00 & 0.00 & 0.00 & 0.01 & 0.00 & $\begin{array}{c}0.025 \mathrm{mg} \text { of } \\
\mathrm{Ni} / \mathrm{L}\end{array}$ \\
\hline $\begin{array}{l}\text { Nitrate (mg of } \\
\mathrm{N} / \mathrm{L} \text { ) }\end{array}$ & 1.12 & 0.37 & 1.63 & 0.80 & 0.95 & 0.95 & 0.75 & $\begin{array}{c}10.0 \mathrm{mg} \text { of } \\
\mathrm{N} / \mathrm{L}\end{array}$ \\
\hline $\begin{array}{l}\mathrm{DO}(\mathrm{mg} \text { of } \\
\left.\mathrm{O}_{2} / \mathrm{L}\right)\end{array}$ & 4.07 & 5.42 & 6.05 & 5.46 & 5.83 & 4.43 & 3.94 & $\begin{array}{c}>5 \mathrm{mg} \text { of } \\
\mathrm{O}_{2} / \mathrm{L}\end{array}$ \\
\hline $\mathrm{pH}$ & 6.12 & 6.42 & 5.95 & 6.03 & 6.37 & 6.29 & 5.83 & 6.0 a 9.0 \\
\hline $\begin{array}{l}\text { Total Solids } \\
(\mathrm{mg} / \mathrm{L})\end{array}$ & 259.67 & 273.67 & 249.83 & 106.67 & 169.17 & 254.00 & 561.00 & --- \\
\hline $\begin{array}{l}\text { Temperature } \\
\left({ }^{0} \mathrm{C}\right)\end{array}$ & 19.44 & 19.18 & 21.68 & 21.81 & 20.53 & 22.41 & 22.68 & --- \\
\hline $\begin{array}{l}\text { Turbidity } \\
\text { (UNT) }\end{array}$ & 24.40 & 32.10 & 6.64 & 15.95 & 32.00 & 27.86 & 17.37 & 100 UNT \\
\hline $\begin{array}{l}\text { Zinc } \\
\text { (mg of } \mathrm{Zn} / \mathrm{L} \text { ) }\end{array}$ & 0.12 & 0.06 & 0.03 & 0.31 & 0.04 & 0.03 & 1.31 & $\begin{array}{c}0.18 \mathrm{mg} \text { of } \\
\mathrm{Zn} / \mathrm{L}\end{array}$ \\
\hline
\end{tabular}

\section{Soil and water relation}

Table 4 and Figure 4 present information on the interactions between the surveys of class and use and occupation of land and location of springs and hydrography.

TABLE 4. Data of soil class and land use and occupation relative to the monitoring springs.

\begin{tabular}{cccccccc}
\hline Spring & N1 & N2 & N3 & N4 & N5 & N6 & N7 \\
\hline Soil class & Argisol & Latosol & Argisol & Cambisol & Argisol & Argisol & Argisol \\
\hline $\begin{array}{c}\text { Use and } \\
\begin{array}{c}\text { Occupation of } \\
\text { land }\end{array}\end{array}$ & Native Forest & Maize & Maize & Pasture & Eucalyptus & Pasture & Pasture \\
\hline
\end{tabular}




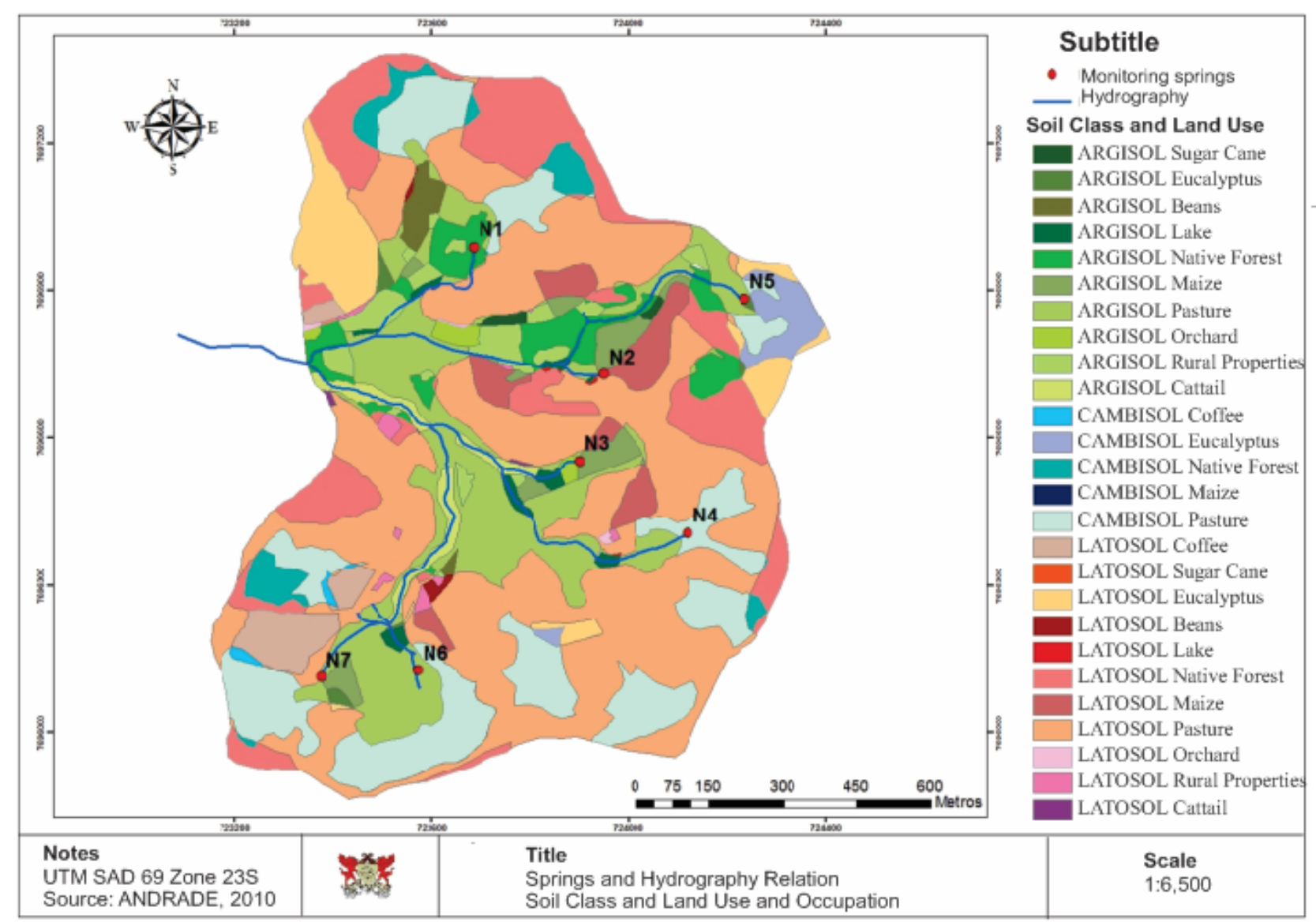

FIGURE 4. Data of hidrography, soil classification, land use and occupation, and location of the springs.

Through the results presented for water quality and land use and classification, it is possible to make a comprehensive analysis of the area.

The parameter $E$. coli did not meet the legal standard only for the result found in N2. The presence of this organism, which is found only in the intestinal tracts of warm-blooded animals, was detected in $90 \%$ of the analysis performed for this spring, showing an indicator of fecal pollution that can be attributed mainly to the vicinity of springs with pasture and rural residences and pollution from animal waste, corroborating the data obtained by SOARES et al. (2011).

The color and BOD parameters showed non-conformities in all monitored springs. Changes on BOD parameter are directly related to the input of organic matter in the water. The color is related to the presence of dissolved compounds in water, which may be organic - decomposition of sewage and leaves - or inorganic - iron and manganese oxides. In the springs analyzed, this parameter showed wide variations, verifying nonconformities in more than $50 \%$ of the samples. Although changes were found throughout the study period, it is possible to observe a higher concentration of non-conformities in the rainy season, from September to December (Figure 1).

Dissolved oxygen is one of the most important parameters for determining the quality of an aquatic environment, and the changes in its concentrations can be natural or anthropogenic, and is directly related to the input of organic compounds in water. The minimum limit set for Class 2 is $5 \mathrm{mg} / \mathrm{L} \mathrm{O}_{2}$. In the surface waters analyzed, approximately $43 \%$ had non-compliances with the legal standard, and it was observed a decrease in the concentration of this parameter in the last two campaigns, which may be explained by the increase of material in suspension due to rains (see Figure 1). Although the average detect changes only at points N1, N6 and N7, the non-conformity to the parameter, considering the entire monitoring period, was observed in the seven springs analyzed. 
In results presented by ANDRADE et al. (2007), this variable presented as a component indicative of the anthropogenic action on water quality in the basin of the Baixo Acaraú. Observing the results found in this work, one may also note the relation between the decrease of DO concentration and anthropogenic activity, since the main changes in this parameter were detected in the spring N7, which, despite being located in an area of native forest, is very close to a rural residence, surrounded by agricultural activity; and springs N6, located in pasture areas and also surrounded by agricultural activity.

The parameters color, BOD and DO are directly related to each other and, in turn, are related to the input of solids and organic compounds in the water. It is observed from Figure 4 and Table 4 that all the springs have some kind of use which contributes to the increase of solids and organic matter in surface waters.

Pasture areas existing in the sub-basin are generally degraded, with the presence of exposed soils, laminar erosion and furrow erosion caused by runoff of rainwater and indiscriminate occupation of permanent protection area (PPA), as it can be seen in Figure 5 photos.
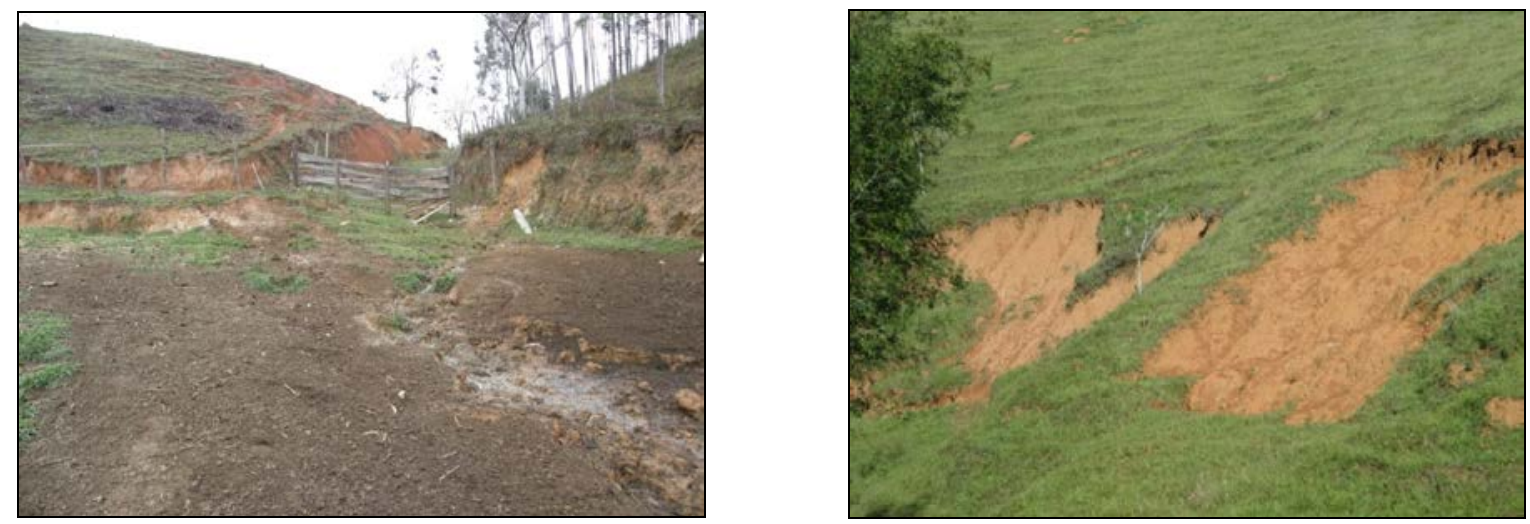

FIGURE 5. Pasture and PPA occupation areas located in the sub-basin.

It is possible to affirm that the entrainment of soil particles resulting from erosion, coupled with the uncontrolled presence of animals in the pastures, is directly related to changes in the parameters color, BOD and DO. The presence of animals in the permanent preservation areas of springs influences both the input of organic matter, due to the release of waste, as the increase in solids concentration due to trampling of these areas.

The results presented so far are similar to results found by MENEZES et al. (2009) for the watershed of São Domingos River (Rio de Janeiro state) (BHRSD), where values of the parameters DO, BOD and fecal coliform were associated with the land use and occupation, the intense releases of agricultural waste and sewage, and animal husbandry in BHRSD.

The $\mathrm{pH}$ of the water was slightly acid, ranging between 5.83 and 6.42, while the $\mathrm{pH}$ values measured in the soil ranged between 3.88 and 6.24, considering all types of soils in the area of study. Therefore, both the soil $\mathrm{pH}$ and the $\mathrm{pH}$ of the water presented acid to slightly acid, and it is possible to observe a relation between the soil and water $\mathrm{pH}$.

According to MATHEUS et al. (1995), the water in the natural environment has a concentration of $\mathrm{H}^{+}$and $\mathrm{OH}^{-}$strongly influenced by salts, acids and bases present in the environment, thus providing information on the quality, type of soil where the water traveled, the type of chemical pollution of water, and environmental quality, corroborating the results presented.

The water temperature showed values between $19.4^{\circ} \mathrm{C}$ to $22.7^{\circ} \mathrm{C}$ (Table 3). The lowest temperature measured throughout the monitoring period was $16.9^{\circ} \mathrm{C}$, and the higher was $30.7^{\circ} \mathrm{C}$, with an average of $21.1^{\circ} \mathrm{C}$. The existing variations coincide with changes in atmospheric temperature and exhibit higher values during the warmer months. 
Lead showed changes in the months of November and December in more than $70 \%$ of samples analyzed, and these were the only non-conformities found throughout the monitoring. Chromium had its concentration increased from the month of September, when there was a change in two of seven samples analyzed, and in the months of November and December there were no changes only in a spring monitored. Nickel, despite increased concentration in the last two months, showed non-conformity in only one sample.

Zinc has a legal limit for surface waters established at $0.18 \mathrm{mg} / \mathrm{L} \mathrm{Zn}$. According to this limit only three changes were found in the campaign in September. If it was considered the standard for drinking water of $5 \mathrm{mg} / \mathrm{L} \mathrm{Zn}$, only one sample would be out of the limit.

Iron was detected in high concentrations in all monitored springs, when compared with the standard for dissolved iron, and manganese showed significantly changes at springs N2, N3, N5, N6 and N7. Analyzing the chemical composition of soils present in the sub-basin, there are iron values ranging from $41,471.4$ to $53,714.9 \mathrm{mg} . \mathrm{kg}^{-1}$ and manganese values ranging from 13.4 to $937.0 \mathrm{mg} . \mathrm{kg}^{-}$ 1 , concentrations much higher than those of the other analyzed elements $(\mathrm{Cu}, \mathrm{Zn}, \mathrm{Cd}, \mathrm{Pb}, \mathrm{Cr}$ and $\mathrm{Ni}$ ). In this sense, we can say that the presence of iron and manganese in water is directly related to the geological and pedological local characteristics. The input of suspended solids is one of the main factors responsible for the increase in the concentration of these elements, since they are present in numerous constituents of rocks and soils, as can be seen in the results presented above. In some springs, it is even possible to observe a gel characteristic of the presence of iron in the water. With regard to the parameter manganese, whose standard is $1 \mathrm{mg} / \mathrm{L} \mathrm{Mn}$, changes also occurred at a higher intensity during the rainy season, although they have been found throughout the entire monitoring.

We also detected changes in the parameters $\mathrm{Cr}$ and $\mathrm{Pb}$, in the campaigns in the rainy season, which were accompanied by the increase of the concentration of total solids. These elements were found in high concentrations for all springs in the monitoring period, with the exception of N1. According to BERTOLO et al. (2009), chromium usually occurs in minerals in the trivalent form, forming insoluble hydroxides and oxides, which explain the low frequency that is detected in the chemical analysis of the water, being found in the present case only during the rainy months. According to AMARAL SOBRINHO et al. (2009), the use of fungicides, herbicides and insecticides contribute to the provision of heavy metals in soil and may contain lead and zinc in their compositions. The chromium in the soil showed values ranging from 13.9 to $61.3 \mathrm{mg} . \mathrm{kg}^{-1}$, and the lead ranged from 38.9 to $64.0 \mathrm{mg}^{\mathrm{kg}}{ }^{-1}$, values that are below the prevention value for soil contamination.

Based on these results, we can say that the most likely cause of water contamination by these elements is the major input of sediment into waterways due to the onset of erosion during the rainy season, allowing them to be identified in larger quantities in the waters analyzed. The impact of the drops of rain on bare soil of pastures accentuates the instability of the particles, which are carried along with organic compounds (leaves, animal waste, etc.) by runoff to areas where the springs are. In the case of lead, it can be associated with the use of pesticides, especially in areas near coffee plantations and also in pasture areas formerly occupied by this type of culture.

Note that in the sub-basin of the Palmital stream the contamination of surface waters has occurred right at their points of upwelling. With this, we can say that in the watercourses the situation should not be different, since, along their trajectories, effluents arising from seepage pits, animal waste and release of raw sewage are still embedded in some points. In this matter, measures involving the sanitary control of the sub-basin are of great relevance to change the scenario of pollution found, including awareness campaigns of the resident population.

Because of this, control over anthropogenic activities is the first step for improving the quality of water resources in the sub-basin. Among the control measures that can be adopted, two are considered of fundamental importance to this area: the isolation of heads and springs of the 
watercourses by fencing, to avoid direct contact of cattle, and the revegetation of riparian vegetation.

\section{CONCLUSION}

The changes found for the water quality in the sub-basin under study are mainly related to the parameters color, BOD, DO, E. coli and total coliform. It can be argued that these changes have their origin mainly in anthropogenic activities and in the land use and occupation.

For some parameters, such as $\mathrm{pH}$, iron and manganese, geology and pedology exert narrow influence and may explain the changes found in the springs. To minimize the input of sediment in springs and watercourses, which increase the concentration of these elements in the water, you need a proper management of the soil, thus avoiding the intensification of erosion processes. In this sense, the decrease in pasture areas, the use of more rational forms of planting, and the reforestation of permanent preservation areas (which include banks of watercourses and the upper third of hills) would be appropriate measures.

It was not possible to identify a relation between soil classes and water quality in the springs. This fact may be explained by the uniformity of the rocky substratum on the sub-basin that reflects the results presented for the metals present in the soil. However, the relation between the land use and occupation and surface water quality was evident, especially when one compares the areas closest to the pastures and the results for the parameters color, DO, E. coli and BOD.

\section{ACKNOWLEDGEMENTS}

The authors thank FAPEMIG, CNPq and CAPES for the financial support to the project.

\section{REFERENCES}

AMARAL SOBRINHO, N.M.B.; BARRA, C.M.; LÃ, O.R. Química dos metais pesados nos solos. Química e mineralogia do solo: Aplicações. Viçosa: Sociedade Brasileira de Ciência do Solo, 2009. 685p.

AMARAL SOBRINHO, N.M.B.; COSTA, L.M.; OLIVEIRA, C.; VELLOSO, A.C.X. Metais pesados em alguns fertilizantes e corretivos. Revista Brasileira de Ciências do Solo, Viçosa-MG, v. 16, p. 271-276, 1992.

ANDRADE, L. C. R. Estudo da influência do meio físico e das atividades antrópicas na qualidade da água na sub-bacia do córrego Palmital - Viçosa/MG. 2010. 151 f. Dissertação (Mestrado em Geotecnia Ambiental) - Universidade Federal de Viçosa, Departamento de Engenharia Civil, Viçosa, 2010.

ANDRADE, E. M. de; ARAÚJO L. F. P.; ROSA, M. F.; DISNEY, W; ALVES, A. B. Seleção dos indicadores da qualidade das águas superficiais pelo emprego da análise multivariada. São Paulo, Brasil. Engenharia Agrícola, Jaboticabal, v.27, n.3. p. 683-690, 2007.

APHA. American Public Health Association. Standard methods for the examination of water and wastewater. 21th ed. Washington, 2005. 1496p.

BARDALES, N. G.; LANI, J. L.; AMARAL, E. F.; MELO, A. W. F. de; ARAÚJO, E. A.; ROSADO, J. F. Uso de Imagens STRM na elaboração de mapa de solos na região do vale do baixo Rio Iaco, Acre, Brasil. In: CONGRESSO BRASILEIRO DE CIÊNCIA DO SOLO, 35., 2007. Gramado. Anais...Gramado: Sociedade Brasileira de Ciência do Solo, 2007. 1 CD-ROM.

BERTOLO, R. A.; MARCOLAN, L. N. O; BOUROTTE, C. Relações água-rocha e a hidrogeoquímica do cromo na água subterrânea de poços de monitoramento multiníveis de Urânia, SP, Brasil. Geologia USP, Série Científica, v. 9, p. 47-62, 2009. 
BRASIL. Conselho Nacional do Meio Ambiente. Resolução nº 357, de 17 mar. 2005. Dispõe sobre a classificação dos corpos de água e diretrizes ambientais para o seu enquadramento, bem como estabelece as condições e padrões de lançamento de efluentes, e dá outras providências. Disponível em: <http://www.mma.gov.br/port/conama/res/res05/res35705.pdf>. Acesso em: 15 out. 2009.

BRASIL. Conselho Nacional do Meio Ambiente. Resolução nº 420, de 28 dez. 2009. Dispõe sobre critérios e valores orientadores de qualidade do solo quanto à presença de substâncias químicas e estabelece diretrizes para o gerenciamento ambiental de áreas contaminadas por essas substâncias em decorrência de atividades antrópicas. Disponível em:

<http://www.mma.gov.br/port/conama/res/res05/res35705.pdf> Acesso em: 18 nov. 2008.

DONADIO, N.M.M.; GALBIATTI, J.A.; PAULA, R.C. Qualidade da água de nascentes com diferentes usos do solo na bacia hidrográfica do córrego rico, São Paulo, Brasil. Engenharia Agrícola, Jaboticabal, v. 25, n.1, p. 115-125, 2005.

EMBRAPA. EMPRESA BRASILEIRA DE PESQUISA AGROPECUÁRIA. Centro Nacional de Pesquisa de Solos. Sistema brasileiro de classificação de solos. 2. ed. Rio de Janeiro: Embrapa Solos, 2006. 306 p.

EPA. United States Environment Protection Agency. An introduction to water quality Monitoring. 1999. Disponível em: <http://www.epa.gov/OWOW/monitoring/monintro.html> Acesso em: nov 2009.

EPA. United States Environment Protection Agency. Method 3050B. Acid Digestion Of Sediments, Sludges, And Soils. 1996. Disponível em:

<http://www.epa.gov/waste/hazard/testmethods/sw846/pdfs/3050b.pdf> Acesso em: dez. 2009.

GIROTTO, E. Cobre e zinco no solo sob uso intensivo de dejeto líquido de suínos. Dissertação (Mestrado em Ciência do Solo) - Universidade Federal de Santa Maria, Centro de Ciências Rurais, Universidade Federal de Santa Maria, Santa Maria.

KESSLER, N.C.H; PASSARIN, O.M; LUCAS, S.D.M; SAMPAIO, S.C. Análise preliminar do comportamento do zinco no solo e no milho (Zea mayz L.) sob aplicação de água residuária da suinocultura. In: SIMPÓSIO INTERNACIONAL SOBRE GERENCIAMENTO DE RESÍDUOS AGROPECUÁRIOS E AGROINDUSTRIAIS, 2., 2011. Foz do Iguaçu. Anais... Foz do Iguaçu: II SIGERA, 2011.

MATHEUS, C. E.; MORAES, A.J. DE; TUNDISI, T.M.; TUNDISI, J.G. Manual de análises limnológicas. São Carlos: Centro de Recursos Hídricos e Ecologia Aplicada, USP, 1995. 62p.

MENEZES, J. M.; PRADO, R. B.; JÚNIOR, G. C. da S.; MANSUR, K. L.; OLIVEIRA, E. dos S. Qualidade da água e sua relação espacial com as fontes de contaminação antrópicas e naturais: bacia hidrográfica do rio São Domingos - RJ. Engenharia Agrícola, v. 29, n.4, p. 687-698, 2009.

MINAS GERAIS. Conselho Estadual de Política Ambiental. Deliberação Normativa n. 166, de 29 jun. 2011. Altera o Anexo I da Deliberação Normativa Conjunta COPAM CERH no 2 de 6 de setembro de 2010, estabelecendo os Valores de Referência de Qualidade dos Solos. Disponível em: < http://www.siam.mg.gov.br/sla/download.pdf?idNorma=18414> Acesso em: 10 abr. 2012.

SANTOS, G. V.; DIAS, H. C. T.; SILVA, A. P. de S.; MACEDO, M. de N. C. de. Análise hidrológica e socioambiental da bacia hidrográfica do Córrego do Romão dos Reis, Viçosa, MG. Revista Árvore, Viçosa-MG, v. 31, n. 5, p. 931-940, 2007.

SOARES, V. P. ; MOREIRA, A. de A ; RIBEIRO, C. A. A. S. ; GLERIANI, J. M. ; JUNIOR, J. G.. Mapeamento de áreas de preservação permanentes e identificação dos conflitos legais de uso da terra na bacia hidrográfica do ribeirão São Bartolomeu, MG. Revista Árvore, Viçosa-MG, v. 35, n. 3, p. 555-563, 2011. 
TERAMOTO, E. R.; LEPSCH, I. F.; VIDAL-TORRADO, P. Relações solo, superfície geomórfica e substrato geológico na microbacia do ribeirão Marins (Piracicaba - SP). Scientia Agricola, Piracicaba, v. 58, n. 2, p. 361-371, 2001.

TUNDISI, J. G. Águas Doces no Brasil. $3^{\mathrm{a}}$ ed. São Paulo: Escrituras Editora, 2006. p. 111-144.

VON SPERLING, M. Introdução à qualidade das águas e ao tratamento de esgotos. Belo Horizonte: Departamento de Engenharia Sanitária e Ambiental, 2011. v. 1. 243p. 